\title{
Peranan Pemuda dalam Meningkatkan Kualitas Ibadah di BNKP Jemaat Hilisawato Simalingkar Medan
}

\author{
Rosmawati Ndraha \\ Sekolah Tinggi Teologi Paulus Medan, Sumatera Utara \\ ndraharosmawati@yahoo.com
}

\begin{abstract}
This study aims to determine whether youth play a role in improving the quality of worship at the Hilisawato Simalingkar Congregation in Medan, to determine the extent of youth involvement in worship services towards improving the quality of worship at the Hilisawato Simalingkar Congregation in Medan. To obtain the required data, this research was conducted with qualitative methods, namely by conducting observations and interviews. The subjects observed by researchers were the Reverend BNKP Hilisawato Simalingkar Medan Church, the BNKP Assembly, the BNKP Youth. The instrument used in this study was the technique of reading and taking notes. Then the data analysis technique used is exposure technique. The results of this study are as follows. First, it is absolutely necessary to involve the youth participating in youth to improve the quality of worship. Secondly, It is impossible to get quality worship without a quality service. Third, Pastors should increase the number of advisory personnel to equip youth before being deployed in worship services so that quality is maintained. Fourth, worship is not just a religious ritual ceremony that must be beautiful only from its aesthetics, but worship involves a lifestyle that is reflected in the behavior of everyday life so that worship becomes a living, holy and pleasing worship to Him.
\end{abstract}

Keywords: BNKP Church; quality of service; worship; youth

\begin{abstract}
Abstrak: Penelitian ini bertujuan untuk mengetahui apakah pemuda berperan untuk meningkatkan kualitas Ibadah di BNKP Jemaat Hilisawato Simalingkar Medan, untuk mengetahui sejauh mana keterlibatan pemuda di dalam pelayanan Ibadah menuju peningkatan kualitas ibadah di BNKP Jemaat Hilisawato Simalingkar Medan. Untuk memperoleh data yang diperlukan, penelitian ini dilaksanakan dengan metode kualitatif yaitu dengan melakukan observai dan wawancara. Adapun Subjek yang diamati oleh peneliti ialah Pendeta BNKP Jemaat Hilisawato Simalingkar Medan, Majelis BNKP, Pemuda BNKP. Instrumen yang digunakan dalam penelitian ini adalah teknik membaca dan mencatat. Lalu teknikanalisa data yang digunakan adalah teknik pemaparan. Hasil Penelitian ini adalah sebagai berikut. Pertama, Adalah mutlak melibatkan pemuda berperan serta pemuda untuk meningkatkan kualitas ibadah. Kedua, Adalah mustahil untuk mendapatkan ibadah yang berkualitas tanpa Pelayan Ibadah yang berkualitas pula. Ketiga, Pendeta hendaknya menambah personil pembina dalam memperlengkapi pemuda sebelum diterjunkan dalam pelayanan ibadah sehingga kualitasnya tetap terjaga. Keempat, Ibadah bukan sekedar upacara ritual keagamaan yang harus indah hanya dari estetikanya saja, tetapi ibadah menyangkut gaya hidup yang tercermin dalam perilaku hidup sehari-hari sehingga ibadah itu menjadi ibadah yang hidup, kudus dan berkenan kepadaNya.
\end{abstract}

Kata kunci: Gereja BNKP; ibadah; kualitas ibadah; pemuda 


\section{PENDAHULUAN}

Gereja yang sehat dan Alkitabiah memiliki keseimbangan dalam pertumbuhan kualitatif, kuantitatif, dan organic. Ron Jenson dan Jim Stevens mengatakan bahwa Pertumbuhan gereja adalah kenaikan yang seimbang dalam kualitas, kuantitas dan kompleksitas organisasi sebuah gereja lokal. ${ }^{1}$

Salah satu usaha gereja untuk meningkatkan kuantitas jemaat adalah melalui peningkatan kualitas ibadah. Dalam meningkatkan kualitas ibadah ini, sedapat mungkin gereja harus memberdayakan banyak pihak dan salah satunya adalah pemuda. Ironisnya, ada saja gereja yang mengabaikan peranserta pemuda dalam usaha peningkatan kualitas ibadah ini, dimana pemuda kurang dilibatkan secara maksimal dalam usaha peningkatan kualitas ibadah. Pemuda hanya dianggap sebagai jemaat awam, sebagai penonton di gereja, bahkan tidak jarang pemuda hanya dijadikan sebagai objek binaan tanpa diberi ruang untuk lebih memberdayakan potensinya. Hal ini tentu sangat disayangkan mengingat pada umumnya kaum muda adalah orang-orang yang memiliki potensi, spirit serta talenta dari Tuhan yang apabila dikelola dengan baik akan sangat bermanfaat bagi peningkatan kualitas ibadah demi mencapai pertumbuhan gereja, secara khusus peningkatan kuantitas jemaat.

Tujuan dilakukannya penelitian ini adalah, untuk mengetahui apakah pemuda berperan untuk meningkatkan kualitas Ibadah di BNKP Jemaat Hilisawato Simalingkar Medan. Dan mengetahui sejauh mana keterlibatan pemuda di dalam pelayanan Ibadah menuju peningkatan kualitas ibadah di BNKP Jemaat Hilisawato Simalingkar Medan.

\section{METODOLOGI PENELITIAN}

Pendekatan penelitian dalam penelitian ini adalah kualitatif, dengan menggunakan metode deskripsif. Pengumpulan data untuk mendukung penelitian ini adalah dengan membaca litaratur terkait baik yang berada di perpustakaan (literatur) maupuan penggunaan internet yang dapat memberi informasi untuk melengkapi data dalam mencari sumber landasan teori. Selain itu juga mengadakan observasi serta wawancara.

\section{Peranan Pemuda}

Istilah peran dalam Kamus Besar Bahasa Indonesia mempunyai arti pemain sandiwara (film), tukang lawak pada permainan makyong, perangkat tingkah yang diharapkan dimiliki oleh orang yang berkedudukan di masyarakat ${ }^{2}$. Istilah peran kerap diucapkan banyak orang. Sering kita mendengar kata peran dikaitkan dengan posisi atau kedudukan seseorang. Atau peran dikaitkan dengan apa yang dimainkan oleh seorang aktor dalam suatu drama. Yang pasti kata peran, atau role dalam bahasa Inggrisnya, memang diambil dari dramaturgy atau seni teater. Dalam seni teater seorang aktor diberi peran yang harus dimainkan sesuai dengan plot-nya, dengan alur ceritanya, dengan lakonnya.

\footnotetext{
1 Ron Jenson dan Jim Stevens, Dinamika Pertumbuhan Gereja (2000), 8

${ }^{2}$ Departement Pendidikan Nasional, Kamus Besar Bahasa Indonesia (Jakarta, Balai Pustaka, 2005), 
Lebih jelasnya kata "peran" atau "role" dalam kamus oxford dictionary diartikan: Actor's part; one's task or function. Yang berarti aktor; tugas seseorang atau fungsi. ${ }^{3}$ Namun dalam perkembangannya pemakaian kata peran tidak lagi terbatas pada panggung sandiwara, tapi dalam semua aspek kehidupan. Ketika istilah peran digunakan dalam lingkungan pekerjaan, maka seseorang yang diberi (atau mendapatkan) sesuatu posisi, juga diharapkan menjalankan perannya sesuai dengan apa yang diharapkan oleh pekerjaan tersebut. Peranan berasal dari kata peran, berarti sesuatu yang menjadi bagian atau memegang pimpinan yang terutama. ${ }^{4}$ Peranan menurut Levinson sebagaimana dikutip oleh Soejono Soekamto, sebagai berikut:

Peranan adalah suatu konsep perihal apa yang dapat dilakukan individu yang penting bagi struktur sosial masyarakat, peranan meliputi norma-norma yang dikembangkan dengan posisi atau tempat tempat seseorang dalam masyarakat, peran dalam arti ini merupakan rangkaian peraturan peraturan yang membimbing seseorang dalam kehidupan kemasyarakatan. ${ }^{5}$

Sebetulnya tidaklah ada kesepakatan yang jelas tentang siapa yang disebut kaum muda. Banyak orang berpendapat bahwa kaum muda itu adalah kelompok manusia yang berusia antara 15 dan 24 tahun (begitulah misalnya kalangan UNESCO). ${ }^{6}$

Masa muda merupakan suatu masa dimana seseorang memiliki banyak kesempatan untuk melakukan berbagai aktifitas dalam kehidupannya. Pada masa ini mereka dapat dikatakan sedang berada dalam masa produktif. Oleh karena itu sangatlah tepat dan efektif apabila kaum muda dilibatkan dalam setiap usaha Peningkatan Kualitas Ibadah demi mencapai pertumbuhan gereja.

\section{Potensi Kaum muda}

Terdapat banyak hal yang dimiliki oleh kaum muda terlebih dengan kemampuan berpikirnya untuk dapat menciptakan suatu inovasi yang terbarukan. Tetapi disamping kelebihan yang dimiliki, kaum mudapun memiliki sejumlah kelemahan dari berbagai segi. Ironisnya, seringkali kelemahan ini yang justru cenderung lebih menonjol ketimbang potensinya. Kaum muda lebih senang berperilaku selayaknya mereka akan terus muda sehingga mereka tidak berpikir jika masih ada hari esok. Terlebih dengan kebebasan yang seluasnya yang diberikan oleh orang tua menjadi sesuatu hal yang lumrah untuk memanfaatkannya dengan sekehendak hatinya. Inilah beberapa faktor yang menyebabkan kecenderungan kaum muda lebih memanfaatkan kelemahannya untuk menciptakan sebuah kesenangan bukan kemajuan kehidupannya.

\section{Idealisme dan Daya Kritis}

Secara sosiologi pemuda belum mapan dalam tatanan yang ada, sehingga ia dapat melihat kekurangan dalam tatanan dan secara wajar mampu mencari gagasan baru. Pengejawan-

\footnotetext{
${ }^{3}$ The New Oxford Illustrated Dictionary, Oxford University Press, $1982 \mathrm{Hal}$

${ }^{4}$ W.J.S. Poerdarminta, Kamus Umum B. Indonesia, PN Balai Pustaka 1984 Hal 735

${ }^{5}$ Soejono Soekanto, sosiologi suatu pengantar, Jakarta, Rajawali Press, 1982 hal 138

${ }^{6}$ Silalahi,P.R, Generasi Muda dalam strategi Pembangunan di Masa Depan, dalam ; Analisa th.VI no. 9 September 1997 hal 3
} 
tahan idealisme dan daya kritis perlu dilengkapi landasan rasa tanggung jawab yang seimbang.

\section{Dinamika dan Kreativitas}

Adanya idealisme pada generasi muda, menyebabkan mereka memiliki potensi kedinamisan dan kreativitas, yakni kemampun dan kesediaan untuk mengadakan perubahan, pembaharuan, dan penyempurnaan kekurangan yang ada ataupun mengemukakan gagasan yang baru demi kemajuan pelayanan.

Keberanian Mengambil Resiko. Dalam mengadakan perubahan dan pembaharuan pastilah pemuda menemukan berbagai tantangan termasuk resiko terpahit berupa kegagalan. Namun, keberanian mengambil resiko itu diperlukan jika ingin memperoleh kemajuan. Pemuda dapat dilibatkan pada usaha-usaha yang mengandung resiko. Untuk itu diperlukan kesiapan pengetahuan, perhitungan dan iman yang teguh dari pemuda sehingga mampu memberi kualitas yang baik untuk berani mengambilresiko.

Optimis. Kegagalan tidak menyebabkan generasi muda patah semangat. Optimisme dan kegairahan yang dimiliki pemuda merupakan daya pendorong untuk mencoba lebih maju lagi.

Sikap Kemandirian dan Disiplin. Pemuda memiliki keinginan untuk selalu mandiri dalam sikap dan tindakannya. Sikap kemandirian itu perlu dilengkapi dengan kesadaran disiplin pada dirinya agar mereka dapat menyadari batas-batas yang wajar dan memiliki tenggang rasa.

Terdidik. Walaupun dengan memperhitungkan faktor putus sekolah, secara menyeluruh baik dalam arti kualitatif maupun dalam arti kuantitatif, pemuda secara relatif lebih terpelajar karena lebih terbukanya kesempatan belajar dari generasi pendahulunya.

Keanekaragaman dalam Persatuan dan Kesatuan. Keanekaragaman pemuda merupakan cermin dari keanekaragaman masyarakat kita. Keanekaragaman tersebut dapat menjadi hambatan jika dihayati secara sempit dan eksklusif. Akan tetapi, keanekaragaman masyarakat Indonesia merupakan potensi dinamis dan kreatif jika ditempatkan dalam kerangka integrasi nasional. Keanegaragaman ini juga sangat strategis apabila dimanfaatkan dalam pelayanan ibadah gereja sehingga lebih kaya wawasan.

Sikap Kesatria. Kemurnian idealisme, keberanian, semangat pengabdian dan pengorbanan serta rasa tanggung jawab sosial yang tinggi adalah unsur-unsur yang perlu dipupuk dan dikembangkan dikalangan pemuda sebagai generasi penerus gereja.

Kemampuan Penguasaan Ilmu dan Teknologi. Pemuda dapat berperan dalam rangka penerapan ilmu dan teknologi untuk kepentingan pelayanan bila secara fungsional dapat dikembangkan sehingga bermanfaat bagi efisiensi dan efektifitas pelayanan unuk menghasilkan ibadah yang berkualitas.

\section{Peranan Pemuda dalam Meningkatkan Kualitas Ibadah}

Pemuda BNKP Jemaat Hilisawato Simalingkar Medan mengambil peran yang cukup strategis dalam upaya meningkatkan kualitas ibadah di BNKP Hs. Simalingkar. Hampir 
dalam setiap kegiatan/tugas-tugas pelayanan di BNKP Jemaat Hilisawato Simalingkar Medan berperan aktif, diantaranya dalam tugas pelayan ibadah sebagai berikut:

- Penerima Tamu

- Singer

- $\mathrm{MC}$

- Kolektan

- Pembaca Warta Gereja

- Pemimpin Pujian

- Pemain Musik

- Multimedia

- Pembicara/Pengkhotbah pada Ibadah Pemuda dan Ibadah Keluarga dan lain-lain

\section{Strategi Pemuda dalam Meningkatkan Kualitas Ibadah}

Adalah mustahil untuk menghasilkan ibadah yang berkualitas jika para pelayan ibadahnya tidak berkualits pula. Maka ketika pemuda BNKP ingin mengambil peranan untuk meningkatkan kualitas ibadah di BNKP Jemaat Hilisawato Simalingkar Medan, mereka tentunya harus terlebih dahulu meningkatkan kualitasnya sebagai pelayan ibadah. Untuk itu mereka mengambil langkah-langkah sebagai berikut:

\section{Meningkatkan Kualitas Kebenaran}

Dalam peningkatan kualitas kebenaran ini, pemuda dibina oleh Majelis dan Gembala Sidang secara berkala. Pemuda juga mengikuti Seminar-seminar yang dilakukan berbagai pihak (sesuai kebutuhan) untuk meningkatkan kualitas kebenaran mereka.Secara rutin sesuai jadwal tahunannya, pemuda juga dibekali melalui kegiatan yang dilakukan oleh Gereja Induk dimana kegiatan itu mempertemukan pemuda dari seluruh BNKP yang ada di Indonesia misalnya acara Youth Camp dll. Peranan Gembala Sidang patut diacungi Jempol dalam usaha peningkatan kualitas kebenaran di BNKP Jemaat Hilisawato Simalingkar Medan dimana Gembala Sidang mensponsori pemuda yang dipandang berpotensi untuk mengikuti jenjang pendidikan formal melalui Sekolah Tinggi Theologi dengan harapan segala pengetahuan tentang Kebenaran Firman Tuhan yang didapat di bangku perkuliahan dapat diabdikan demi peningkatan kualitas ibadah di BNKP Jemaat Hilisawato Simalingkar Medan atau dimanapun kelak ia berada.

\section{Meningkatkan Kualitas Kekudusan}

Kualitas kekudusan menyangkut perilaku hidup sehari-hari sehingga para pemuda dapat meningkatkan kualitas ibadah tidak hanya dari segi estetika atau kemasan, melainkan benar-benar merupakan persembahan yang hidup oleh kuasa Roh, sehingga tidak terjadi ibadah yang penuh dengankemunafikan seperti tertulis dalam Mat 15:7-8, "Hai orangorang yang munafik! Benarlah nubuat Yesaya tentang kamu: Bangsa ini memuliakan Aku dengan bibirnya, padahal hatinya jauh dari padaKu." Usaha peningkatan Kualitas kekudusan ini ditempuh dengan rajin mengikuti Kebaktian Raya setiap hari Minggu. Pemuda juga mempunyai kebaktian sendiri Melaksanakan PA setiap hari Sabtu pukul 19.00 WIB. Sejauh pengamatan selama melakukan observasi, kehadiran anggota pemuda 
di dalam ibadah kaum muda setiap minggunya cukup baik yaitu berkisar antara 60 hingga 85 persen.

\section{Meningkatkan Kualitas Keindahan}

Untuk meningkatkan kualitas keindahan atau estetika dari pelayan ibadah, pemuda di Gereja BNKP Hs. Simalingkar secara rutin mengadakan latihan setiap Hari Kamis mulai pukul 20.00 wib malam sampai selesai. Latihan meliputi Vocal Group, Singer dan lain lain yang dipandang perlu. Di samping itu, secara rutin Gembala Sidang juga memimpin acara Evaluasi Pelayan Ibadah yang dilakukan setiap Hari Jumat mulai pukul 20.00 wib malam sampai selesai. Kegiatan ini memungkinkan segala kekurangan dalam pelayanan ibadah yang sudah terlewati dapat dikoreksi untuk kemudian diperbaiki. Dengan demikian diharapkan kualitas keindahan dari pelayan ibadah tetap terjaga bahkan hari lepas hari akan semakin mengalami peningkatan.

\section{HASIL DAN PEMBAHASAN}

Dari wawancara tentang Peranan Pemuda dalam meningkatkan kualitas ibadah yang dilakukan oleh peneliti mendapatkan hasil sebagai berikut:

\section{Pemuda Gereja}

1). Berdasarkan Firman Tuhan tentang" ibadah yang sejati" ( Roma 12,1), Maka pemuda BNKP Jemaat Hilisawato Simalingkar Medan menyatakan bahwa Ibadah tidak sekedar mengikuti upacara ritual keagamaan, tetapi harus menjadi gaya hidup, dimana perilaku hidup kita sehari-hari harus sesuai dengan kebenaran Firman Tuhan.

2). Pemuda BNKP Jemaat Hilisawato Simalingkar Medan, berbicara tentang peranan pemuda dalam meningkatkan kualitas ibadah, menyatakan bahwa sebagai pemuda, kadang mereka kurang percaya diri dalam tugas pelayanan ibadah, namun berkat bimbingan dan pembekalan dari Gembala sidang, pemuda siap sedia dalam tugas pelayanan.

3). Pemuda BNKP Jemaat Hilisawato Simalingkar Medan, menyatakan dengan sesungguhnya bahwa sangat mendukung untuk melibatkan peranan pemuda dalam meningkatkan kualitas ibadah.

4). Pemuda BNKP Jemaat Hilisawato Simalingkar Medan menyatakan akan senantiasa bersungguh-sungguh membekali diri melalui latihan dan pembinaan agar dapat menjadi pelayan ibadah yang berkualitas.

\section{Pendeta Jemaat}

Saran dan tanggapan Pendeta Jemaat BNKP Hs. Simalingkar yang menyangkut Peranan Pemuda dalam meningkatkan kualitas Ibadah adalah sebagai berikut: Apabila kita bertanya tentang apa dan bagaimana Gereja di masa depan, sesungguhnya sangatlah tergantung kepada bagaimana kita, para generasi tua terutama hamba Tuhan membentuk, membina dan mempersiapkan pemuda yang tentunya akan menjadi Pemimpin-pemimpin Gereja masa depan. Pengajaran dan Pembinaan terhadap kalangan pemuda Gereja adalah satu hal yang mutlak mengingat tantangan yang akan dihadapi dalam menuju kemajuan Gereja di masa yang akan datang. Pendeta Jemaat BNKP Hs. Simalingkar sangat 
mendukung untuk melibatkan peran serta pemuda dalam meningkatkan kualitas ibadah karena itulah salahsatu upaya Gereja untuk mempersiapkan pemuda menjadi Pemimpin gereja di masa yang akan datang.

Apabila Pemuda dilibatkan dalam peningkatan kualitas ibadah,akan menjadi nilai tambah bagi gereja sebagai berikut:

1) Gereja akan semakin maju dalam pelayanan karena memiliki generasi muda yang terampil dan berkarakter baik yang siap membantu dalam pelayanan.

2) Para jemaat, terutama para orangtua akan mengalami kegirangan karena anakanak mereka aktif menjadi pelayan ibadah sementara ada banyak orangtua yang dilanda kecemasan karena anak-anak mereka terperosok dalam lembah kegelapan,

3) Gereja akan semakin memperbaiki diri dalam kegiatan ibadah yang lebih profesional dan tetap terjaga kualitasnya.

4) Gereja, terutama Kaum muda akan semakin terpacu untuk belajar dan terus belajar, menuntut ilmu demi meningkatkan kualitasnya.

\section{Tokoh BNKP}

Saran dan tanggapan tokoh gereja BNKP Hs. Simalingkar terhadap peranan pemuda dalam meningkatkan kualitas ibadah adalah sebagai berikut:

Selayaknyalah memang bahwa peranan pemuda harus dilibatkan dalam setiap usaha meningkatkan kualitas ibadah. Hal ini mengingat bahwa pemuda adalah Generasi Penerus Gereja yang pada zamannya nanti akan menjadi pemegang tongkat estafet kepemimpinan. Namun melibatkan peran serta pemuda tanpa terlebih dahulu membina dan membekali terutama dari segi kerohanian adalah sesuatu yang konyol, ibarat melepas tentera ke medan perang tanpa memperlengkapinya dengan senjata. Para hamba Tuhan harus selalu menanamkan dalam diri pemuda bahwa kemudaan mereka tidak menjadi penghalang untuk menjadi pelayan ibadah bahkan menjadi teladan asalkan mereka taat dan setia kepada Tuhan, seperti Timotius, anak Rohani Rasul Paulus yangdalam usia belia menjadi pelayan Tuhan (1Tim. 4:12). ${ }^{7}$ Ia benarbenar terlatih di dalam pelayanan dan kepatuhannya telah menjadi teladan bagi oranglain. Dengan pemahaman ini diharapkan para pemuda menjadi percaya diri sehingga mau terlibat dalam pelayanan dan selalu taat mengikutilatihan dan pembinaan, sehingga mereka benar-benar siap menjadi pelayan yang berkualitas.

\section{Temuan}

Dari hasil wawancara dengan para pemuda BNKP Jemaat Hilisawato Simalingkar Medan, Gembala Sidang dan Tokoh BNKP , maka ditemukan bahwa ketiganya sangat mendukung supaya pemuda berperan aktif dalam usaha peningkatan kualitas ibadah, dan para Hamba Tuhan fokus untuk melakukan pembinaan kepada kaum muda.

\footnotetext{
${ }^{7}$ Desti Samarenna and Harls Evan R. Siahaan, “Memahami Dan Menerapkan Prinsip Kepemimpinan Orang Muda Menurut 1 Timotius 4 : 12 Bagi Mahasiswa Teologi," BIA': Jurnal Teologi dan Pendidikan Kristen Kontekstual 2, no. 1 (2019): 1-13, http://www.jurnalbia.com/index.php/bia/article/view/60.
} 


\section{KESIMPULAN}

Pemuda berperan untuk meningkatkan kualitas Ibadah di BNKP Jemaat Hilisawato Simalingkar Medan. Keterlibatan pemuda di dalam pelayanan Ibadah menuju peningkatan kualitas ibadah di BNKP Jemaat Hilisawato Simalingkar Medan sangat berperan.

\section{REFERENSI}

Barclay, William. Mengkomunikasikan Injil, Jakarta: BPK Gunung Mulia, Cetakan ke 4, 2000.

Bensonat. Et. al Pedoman Lengkap Untuk Pelayanan Kaum Muda, (Bandung: Yayasan Klam Hidup)

Bonke, Reinhad. Penginjilan Dengan Api, (Jakarta: Yayasan Injil Immanuel)

Bowncle, Malcom. Hai Pemuda Pililah! Menghadapi masalah-masalah Etika Pemuda, Jakarta: BPK Gunung Mulia, 2000.

Departement Pendidikan Nasional, KBBI Jakarta, Balai Pustaka, 2005.

Jenson, Ron dan Jim Stevens. Dinamika Pertumbuhan Gereja, 2000

Narammore, Mark. Menuju Citra Dini Kristus. Jakarta : Bina Komunio, 2000

Poerdarminta, W.J.S. Kamus Umum B. Indonesia, PN Balai Pustaka 1984

Silalahi, P.R. Generasi Muda dalam strategi Pembangunan di Masa Depan, dalam ; Analisa th.VI no. 9 September 1997

Soekanto, Soejono. Sosiologi suatu pengantar, Jakarta: Rajawali Press, 1982

Soekanto, Soekanto. Remaja Dan Masalahnya, Yogyakarta : Kanisius dan Jakarta: BPK Gunung Mulia, 1998

Samarenna, Desti, and Harls Evan R. Siahaan. "Memahami Dan Menerapkan Prinsip Kepemimpinan Orang Muda Menurut 1 Timotius 4 : 12 Bagi Mahasiswa Teologi." BIA ': Jurnal Teologi dan Pendidikan Kristen Kontekstual 2, no. 1 (2019): 1-13. http://www.jurnalbia.com/index.php/bia/article/view/60.

The New Oxford Illustrated Dictionary, Oxford University Press, 1982 